\title{
Diálogos com Fernando Peixoto ou inquietações em torno do binômio entre arte e política ${ }^{1 *}$
}

Dialogues with Fernando Peixoto or surveys around the binomio between art and politics

\section{Rosangela Patriota}

Rosangela Patriota Professora Assistente Doutora I do Programa de Pós-Graduação em Educação, Artes e História da Cultura da Universidade Presbiteriana Mackenzie. Professora Titular aposentada do Instituto de História da Universidade Federal de Uberlândia (UFU). Bolsista Produtividade do CNPq

* As reflexões aqui apresentadas são parte dos resultados do projeto de pesquisa "O Brasil da Resistência Democrática: o espaço cênico, político e intelectual de Fernando Peixoto (1970-1981)", financiado pelo CNPq por meio de concessão de Bolsa PQ e Edital Universal. O trabalho completo, em breve, virá a público, em formato livro.

1 Sobre essa companhia, consultar Patriota (2018).

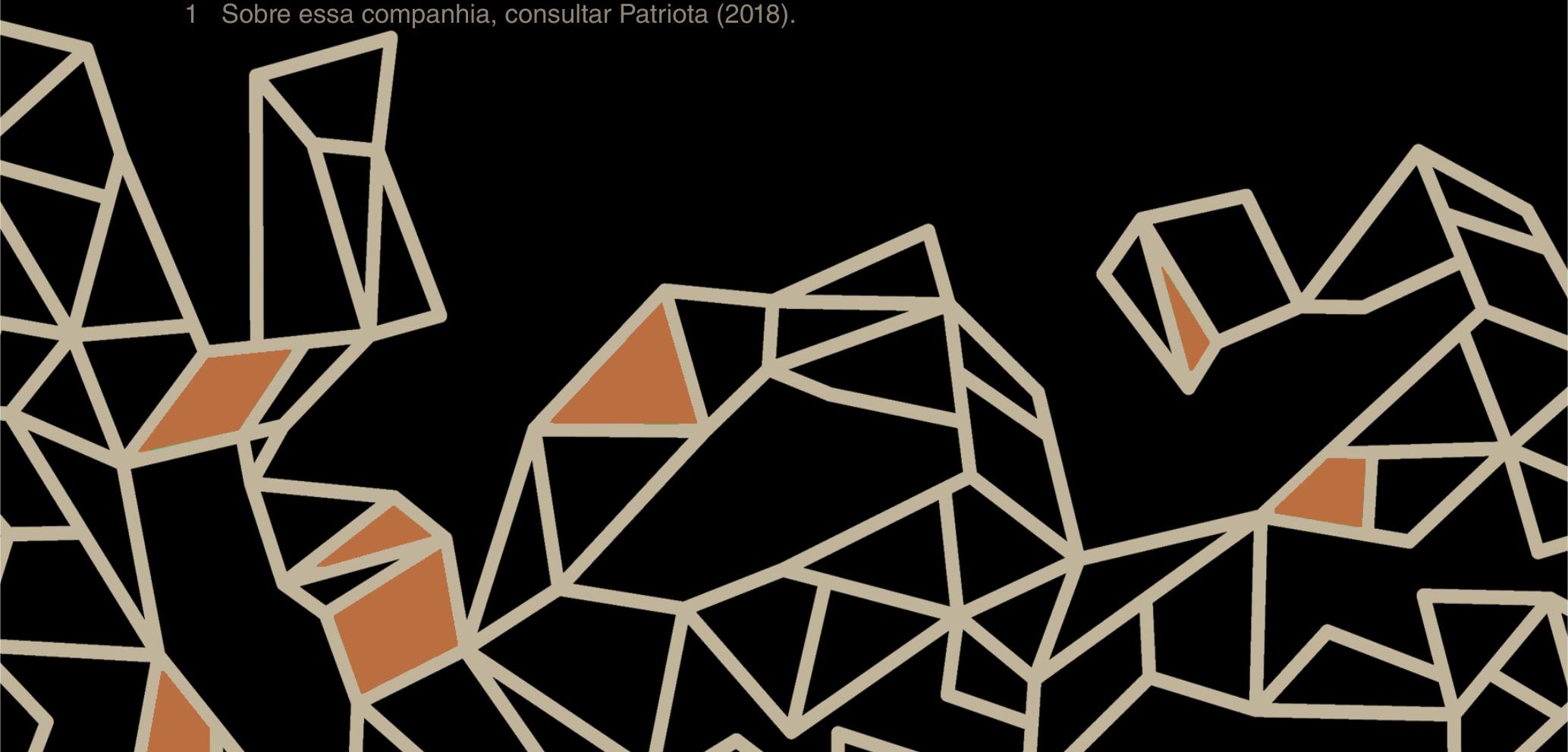




\section{Resumo}

Este artigo visa apresentar momentos importantes da trajetória artística do diretor, ator e escritor Fernando Peixoto (1937-2012). Com esse intuito, serão abordadas suas atividades na cidade de Porto Alegre, onde iniciou sua vida teatral, e na sequência a consolidação de sua trajetória política e profissional, na cidade de São Paulo, no Teatro Oficina, no Theatro São Pedro e na Othon Bastos Produções Artísticas, além de espetáculos não vinculados a companhias específicas.

Palavras-chave: História e teatro, Arte e política, Fernando Peixoto, Teatro brasileiro, Década de 1970.

\section{ABSTRACT}

This article aims to present important moments of the artistic trajectory of the director, actor and writer Fernando Peixoto (1937-2012). To this end, his activities will be approached in the city of Porto Alegre, where he began his theatrical life, and following the consolidation of his political and professional career, in the city of São Paulo, at the Oficina Theater, at the Theatro São Pedro and at Othon Bastos Artistic Productions, as well as shows not related to specific companies.

Keywords: History and theater, Art and politics, Fernando Peixoto, Brazilian theater 1970s.

A verdade é filha do tempo e não da autoridade. A nossa ignorância é infinita, vamos reduzi-la de um centímetro! De que vale ser tão esperto agora, agora que finalmente poderíamos ser ao menos um pouco menos estúpidos! Eu tive a felicidade inimaginável de encontrar um instrumento novo, que permite examinar mais de perto, não muito, uma franja do universo. os senhores deveriam aproveitar. Bertolt Brecht, $A$ vida de Galileu (Galileu Galilei, personagem)

\section{Circunstanciamentos históricos preliminares}

Há sete anos, precisamente no dia 15 de janeiro de 2012, Fernando Amaral dos Guimarães Peixoto saia definitivamente de cena. Nascido em 19 de maio de 1937, na cidade de Porto Alegre, Fernando Peixoto, como ficou nacional e internacionalmente conhecido e reconhecido, deixou um grande 
legado como ator, diretor, escritor e tradutor. Apesar das inegáveis competências mencionadas, ele pode ser simplesmente identificado como um homem de teatro que, para além das qualidades artísticas, isto é, habilidades técnicas que lhe permitiram desenvolver, com grande competência, o seu ofício, foi, sobretudo, um homem de ideias, que se traduziram, de forma sistemáti$\mathrm{ca}$, em suas escolhas profissionais e pessoais.

No entanto, mesmo com esse grande destaque na cena teatral brasileira dos últimos cinquenta anos, nos dias de hoje, o seu nome e trajetória são figuras bissextas nas discussões contemporâneas sobre artes cênicas, inclusive entre aqueles que estão voltados para a preservação da memória das artes no país, porque, como se sabe, os esforços empreendidos em torno do processo de memorização são oriundos de escolhas seletivas e, em vista disso, não se deve ignorar que o rememorar não é destituído de intencionalidades.

Todavia, não se pode e nem se deve individualizar esse esquecimento, na medida em que ele é fruto de escolhas históricas, muitas vezes traduzidas na busca por outras opções estéticas e narrativas. Por esse motivo, é preciso indagar: com o retorno do Estado de Direito e a posse, em 1985, de José Sarney como primeiro presidente civil, após os 21 anos de ditadura militar (1964-1985), quais caminhos se apresentaram para o teatro?

Muitos artistas, que atuaram firmemente em projetos vinculados ao tema da resistência democrática, retiraram-se da cena teatral. Antigos atores/produtores encerraram suas atividades como proponentes e passaram a participar de projetos quando convidados, assim como propostas nascidas no decorrer dos anos 1970 esgotaram-se e seus integrantes encaminharam-se para outros veículos de trabalho, tais como a televisão e o cinema.

Com o paulatino desaparecimento da dramaturgia e da cena mais politizada, no sentido clássico, ao lado da extinção de diversos grupos que surgiram nos anos 1970, os palcos brasileiros passaram a dar maior visibilidade a trabalhos e temas que, em menor grau, se faziam presentes desde o final da década de 1960.

$\mathrm{O}$ ambiente político e cultural transmutara-se e isso não pode ser desvinculado do impacto das mudanças ocorridas no Brasil, em especial, aquelas propiciadas pelos governos militares e por diversos segmentos sociais. Dentre elas, cumpre mencionar: modernização conservadora, reforma educacional e investimento em telecomunicações. Tais acontecimentos, aliados 
à atmosfera de censura e de repressão, contribuíram para o estabelecimento do repertório cultural e político da juventude do início dos anos de 1970 que, pelas circunstâncias de época, foi, gradativamente, se revelando diverso daquele que alimentou os jovens das décadas de 1950 e 1960.

Esses artistas, oriundos de segmentos de classe média, não se reconheceram nas proposições de luta e de resistência clamadas pela dramaturgia de Gianfrancesco Guarnieri, Oduvaldo Vianna Filho (Vianinha), Carlos Queiroz Telles, Chico Buarque, Augusto Boal, entre outras, porque o convívio em uma sociedade democrática, aberta ao debate público e formativo, fora uma experiência e uma perda para aqueles que a vivenciaram antes de 1964 e, em muitos casos, esse sentimento não foi compartilhado por quem apenas teve notícias dessas vivências.

Assim, enquanto os artistas comprometidos com a tese da resistência democrática enxergavam a luta política sob o prisma da tragédia, os que não compartilhavam dessa premissa enxergaram o processo sob a égide da comédia, dessacralizando o campo da política, que passou a ser abordado com ironia e não mais com a magnitude da dramaturgia engajada.

Em meio a essas mudanças, no decorrer das décadas de 1980 e de 1990, a figura do diretor tornou-se referência para inúmeros espetáculos, vide nomes como os de Antunes Filho, Gerald Thomas, Gabriel Vilela, Ulisses Cruz, entre outros. Novas companhias ocuparam o espaço cênico: Centro de Pesquisas Teatrais (CPT), do Sesc-SP, a Companhia Estável de Repertório ${ }^{1}$, o Grupo Tapa², o Grupo Galpão, o Teatro Oficina Uzyna Uzona, a Companhia Ópera Seca, entre várias outras.

Já no início dos anos de 1990 surgiram novas companhias. O Rio de Janeiro acolheu, entre outras, a Armazém Companhia de Teatro, criada em Londrina, PR, e a Companhia dos Atores. Por sua vez, a cidade de São Paulo sediou o Folias D'Arte, o Teatro da Vertigem, a Companhia do Latão, os Parlapatões, a Cia Livre, Cemitério de Automóveis, os Satyros etc. Nelas encontram-se importantes diretores (Paulo Moraes, Enrique Diaz, Antônio Araújo, Cibele Forjaz, Marco Antônio Rodrigues, Sérgio Carvalho), atores de grande densidade interpretativa, além de outros núcleos criadores (dramaturgos, cenógrafos,

1 Sobre essa companhia, consultar Patriota (2018).

2 Está em fase de preparação a confecção de um livro sobre esta companhia teatral sob minha responsabilidade. 
iluminador etc.), capazes de produzir espetáculos inquietantes, nos quais a fragmentação do mundo contemporâneo é exposta a partir de situações que envolvem sentimentos, sensações, vontades e condições de existência.

Constata-se, assim, uma evidente pluralidade nos palcos, mas isso não é inusitado, uma vez que a diversidade sempre foi uma constante do teatro brasileiro. Todavia, nesse processo, o aspecto original reside no fato de que, em termos de história recente, o denominado teatro político, que eu prefiro qualificar como explicitamente político, foi redimensionado. As buscas de sentidos, por meio de projetos, muitas vezes, definidos a priori foram, a pouco e pouco, desaparecendo e em seu lugar adquiriram evidências espetáculos nos quais a apreensão antropológica, étnica, comportamental tornara-se o leitmotiv.

Enfim, eu não diria que há um motivo e/ou causa, mas perspectivas mais abrangentes e posturas ideológicas explicitamente definidas foram alijadas do centro do debate teatral e, com elas, aqueles que advogaram a sua presença no processo criativo foram sendo relegados às páginas da história do teatro brasileiro que, em inúmeras circunstâncias, são vistas como folhas mortas. Dentre os que foram agraciados como mais um nome na estante está Fernando Peixoto, que, nas palavras de Orlando Miranda, foi assim descrito:

Sua visão é, necessariamente, a de alguém que tem a seu favor não apenas o talento e a inteligência crítica que todos Ihe reconhecem, mas, sobretudo, a experiência de quem vivenciou muitas etapas de nossa evolução teatral, particularmente a que transcorreu durante a década de 60 , quando aqui se praticou uma dramaturgia sob pressão ou, como já se disse, uma 'dramaturgia de resistência'. [...] Sua concepção do espetáculo teatral reflete, como se sabe, um visceral engajamento no processo histórico, na crença de que o ser humano por estar integrado nesse processo, sofre inevitáveis e fundas mudanças em sua maneira de ver o mundo, de interpretar uma sociedade que, acima de tudo, ele pretende corrigir e aperfeiçoar a fim de que a vida se torne mais justa e mais humana. (MIRANDA, 1988, p. 3)

\section{Fernando Peixoto - de Porto Alegre a São Paulo}

A opinião emitida por Miranda soa como uma bela síntese da presença de Fernando Peixoto na cultura teatral do país, mas acerca de seus interesses 
e percurso formativo o que se sabe? A jornalista, cronista e atriz Ivette Brandalise em seu rememorar fez as seguintes considerações:

Era apenas uma ruela escura, sem nenhuma graça. Um lugar meio perdido, uma ruazinha encolhida onde o sol fazia forfait e a unidade era aguardada nas paredes das casas. À noite, algumas poucas lâmpadas amarelavam o nosso medo, enchendo de sombras o lugar deserto.

Um único motivo justificava a passagem pela rua: a persistência da família Peixoto, que continuava lá, cobrindo as sólidas mesas de jacarandá maciço com toalhas de crochê, enquanto as franjas de cristal do lustre brilham como gotas de um passado colorido. Cadeiras de espaldar alto obrigavam os herdeiros da casa da Travessa do Carmo a manter a mesma postura ereta e a mesma dignidade dos ancestrais.

Uma saleta apinhada de discos e livros era o nosso refúgio, quando visitávamos a casa. Ensaios, estudos, textos de teatro saltavam da arca antiga, ou detrás dos livros da estante, ou até mesmo de dentro das gavetas. Raridades bibliográficas conseguidas em longas tardes dentro de sebos bolorentos, discos antigos, onde, em 78 rotações, Gardel debulhava tangos e o jazz recompunha sua história.

$E$ as vozes eram jovens, o entusiasmo jovem, as crenças jovens, o riso jovem. Fernando Peixoto era o anfitrião e nós, os convidados. O assunto: teatro. Nós estávamos ali para falar de teatro, para discutir, para estudar teatro, para ler sobre teatro, para tentar dar forma concreta ao nosso amor pelo teatro. Fizemos e deixamos de fazer teatro, alguns partiram para São Paulo ou Rio, Fernando foi dirigir o Teatro Oficina de São Paulo e a Travessa do Carmo deixou de fazer parte de nossas vidas. Por muitos anos. (BRANDALISE, 1997, p. 19)

Já Fernando Peixoto, ao comentar o relato da amiga, fez alguns reparos ao dizer:

A Travessa do Carmo, na Cidade Baixa, onde nasci no número 121 (hoje a casa não existe mais) e onde vivi até bem pouco antes de deixar Porto Alegre. Filho de uma professora primária e de um empregado de comércio, tenho certeza de que a casa não tinha as "sólidas mesas de jacarandá maciço" que Ivette "recorda" com carinho; mas ela está certa quando descreve a presença, naquela casa, entre aquelas paredes, de um fantasma que a todos nós envolvia e era feito de paixão: o teatro. Hoje o local é um espaço aberto no Mercadão da Praia das Belas. (PEIXOTO, 1997, p. 15)

Mesmo com as restrições feitas à crônica de Brandalise ao recriar, através da memória, imagens, sons, odores e sensações, a atmosfera de uma juventude motivada pelo conhecimento e pelo desejo de trilhar os caminhos do teatro, 
Fernando revelou um traço que foi por ele preservado: um ambiente de profundo amor e respeito ao conhecimento, à arte e à cultura. Esse interesse fora despertado pelo cinema e estimulado no próprio ambiente familiar, pois a professora primária Nanci e o operário Luiz Peixoto, por desejarem que o filho tivesse uma vida diferenciada da deles, procuraram estimular tais interesses no rapaz.

Ganhei uma máquina de escrever quando era criança. Eu queria fazer um fichário dos filmes que assistia, três ou quatro por semana. Quando Johnny Weissmuller deixou de ser "Tarzan", substituído por Lex Baxter, comecei a comprar revistas sobre cinema, principalmente Carioca e $A$ Cena Muda. Descobri as críticas sobre os filmes e me surpreendi com análises que me despertaram inesperada consciência sobre o significado do cinema. Ainda menor de idade consegui entrar para o Clube de Cinema de Porto Alegre e devorar os clássicos do cinema mudo, principalmente soviéticos, alemães e norte-americanos. $\mathrm{E}$ a ter meus primeiros amigos que não eram colegas de colégio nem parentes nem moravam perto de casa. Entre eles, alguns jornalistas. Um deles, José Silveira, escrevia num jornal de circulação reduzida em Porto Alegre, O Repórter. Quando assisti Um Lugar ao Sol (A Place in the Sun) de George Stevens, pela primeira vez escrevi algumas linhas sobre o filme. Silveira publicou no dia 18 de abril de 1953 em O Repórter. Eu tinha quinze anos. Minha máquina de escrever ganhou um significado novo: logo depois publiquei textos curtos (o primeiro foi Shakespeare no Cinema) num jornal do Colégio Anchieta, onde eu estudava. Eu queria fazer cinema e, morando em Porto Alegre, a decisão foi buscar um atalho: o teatro amador. (PEIXOTO, 2002, p. 17)

Dessas motivações nasceu o jornalista Fernando Peixoto que, a convite de Olga e Carlos Reverbel, publicou, em outubro de 1956, o artigo "O problema da direção no teatro", no "Suplemento Literário" do jornal Correio do Povo. Foram inúmeros textos e entrevistas, com isso, a máquina de escrever se transformara em instrumento de trabalho ${ }^{3}$. Porém, e o teatro? Como ele se inseriu nessa trajetória, ou melhor, como Peixoto tornou-se um homem de teatro?

Comecei a fazer teatro porque queria fazer cinema. [...] Em Porto Alegre não havia outra opção, como ponto de partida para chegar ao cinema. Acabei mergulhado no teatro até o pescoço. Quando garoto eu detestava teatro.

3 É importante salientar que a atividade como jornalista foi exercida por Fernando Peixoto, de maneira sistemática, até o início da década de 1980, em jornais como Opinião, Movimento e A Voz da Unidade. Como escritor, publicou inúmeros livros como Maiakovski, vida e obra, Teatro em Pedaços, Teatro em Movimento, entre outros. 
Meus pais insistiam em tentar me levar para assistir a espetáculos, mas eu resistia. Eu passava tardes e noites mergulhado, hipnotizado, naquilo que para mim resumia o sentido de tudo: o cinema. [...] Lembro de alguns espetáculos que cheguei a ver, quase forçado: um sofá no meio de paredes pintadas, gente se mexendo num espaço ridículo, uma afetação irritante, falando coisas que não me diziam respeito. (РEIXOTO, 1997, p. 20-21)

Estabeleceu-se a relação de amor e ódio. O cinema, sinônimo da modernidade, da narrativa ágil, múltipla e fragmentada, em oposição àquela arte milenar que parecia congelada no tempo e no espaço. A bem dizer, no universo de Peixoto surgiu uma disputa profundamente desigual e nessa contenda o teatro tinha pouquíssimas possibilidades de êxito até que um dia fora praticamente intimado a acompanhar sua tia em um espetáculo do Teatro do Estudante do Rio Grande do Sul, A verdade de cada um, de Luigi Pirandello. Naquele momento, outra forma de fazer teatral descortinou-se sob seus olhos e nele despertou a vontade de ser ator, que fora recebida com reservas pelos pais. Apesar dos incentivos recebidos, em direção a uma formação cultural, provavelmente eles não vislumbravam ter um ator na família. A sensação de incômodo gerada pela escolha pelo tablado, associada a divergências políticas e de visões de mundo, propiciou a Fernando Peixoto revolver suas lembranças de maneira terna e comovida.

Minha mãe não aceitava com facilidade as minhas chegadas em casa às sete horas da manhã. Mas no dia da estreia me deu um exemplar de Hamlet com uma dedicatória que lembro até hoje: 'recuerdo de las madrugadas!'. Meus pais nunca criaram problemas com minha opção pelo teatro. Mas lembro o rosto de meu pai, uma noite, num camarim do Teatro São Pedro, em Porto Alegre, onde eu fazia Anjo de Pedra, de Tennessee Williams, com o TBC, me levou um recado de casa, me olhou com certa tristeza e me disse uma frase que nunca esqueci: 'não gosto de te ver assim, com o rosto pintado'. Ainda hoje penso nisso.

Quando eu era garoto chamava-o de 'amigo', nunca de 'pai.' Meu pai foi operário. Sempre quis que eu tivesse uma profissão 'sem patrão'. TrabaIhou a vida inteira, descansando na sinuca e nas arquibancadas de futebol, onde morreu assistindo a uma derrota de seu time, o Grêmio. Uma de nossas disputas foi sempre minha posição intransigente de torcedor incondicional do Internacional. Lembro de meu pai, roupas sujas, no armazém junto ao cais, onde trabalhava. Getulista, no dia do suicídio ele estava revoltado e eu afirmava em casa 'morreu o ditador!' Sem saber o quanto 
significava aquela morte. Num de meus últimos dias em Porto Alegre, lembro que, rapidamente, no carro sem provocar grandes discussões, ele me disse: 'cuidado com a política, os que estão por cima sempre ganham, os de baixo é que levam as bordoadas'. (PEIXOTO, 1997, p. 26-27)

Em meio a divergências e afetos, o jovem Fernando fizera suas escolhas e em vista disso, em 1958, ingressou na primeira turma do curso de Arte Dramática, na Universidade do Rio Grande do Sul, onde foi aluno de Gerd Bornheim, Ângelo Ricci, Guilhermino César e Ruggero Jacobbi. Sobre este último, afirmou:

Ruggero foi a pessoa que formou a minha cabeça em todos os sentidos. Foi um grande amigo, além de ser professor, e fez esse curso (de direção teatral) para mim e para o Armando para desenvolver internamente uma inquietação que nos levasse a nos transformar, realmente, em diretores. Foi quem me formou artisticamente, culturalmente, quem me formou inclusive politicamente. Ele me deu para ler pela primeira vez Marx, Engels, a Estética de Hegel, me deu Brecht pela primeira vez, me explicou o que era o teatro político, Piscator... Foi quem me formou e quem me pôs na cabeça uma coisa que acho essencial para a minha trajetória como diretor. É uma postura pessoal, não é uma regra, mas é a forma como eu vejo o teatro. (GARCIA, 2002, p. 78)

Ainda em sua cidade natal, Peixoto fundou o Teatro Equipe, nos moldes do Teatro de Arena de São Paulo, pois ele "era nosso modelo como postura de um teatro social, político, voltado para a realidade nacional" (GARCIA, 2002, p. 79). Nessa época, já havia estabelecido contatos com Augusto Boal e Sábato Magaldi e, em 1963, mudou-se definitivamente para a capital paulista, em companhia da atriz Ítala Nandi, à época, sua esposa.

A afinidade com os projetos do Arena era visível, mas o convite para se transferir para São Paulo partiu do Teatro Oficina para atuar na montagem de Quatro num Quarto (V. Katáiev). Posteriormente, atuou em Pequenos Burgueses (Máximo Gorki). Aos poucos, juntamente com Zé Celso, Ítala e Renato Borghi, assumiu a direção administrativa da companhia e esteve presente como ator e/ou assistente de direção em todos os espetáculos do Oficina, na década de 1960.

As duas primeiras direções teatrais de Fernando Peixoto, em São Paulo, foram também no Teatro Oficina. Até então, nessa área, constavam somente as montagens de Matar (Paulo Hecker Filho), em 1959, e em 1961, de Pedro Mico (Antônio Callado), ambas no Teatro Equipe. No entanto, as expectativas 
profissionais envolvendo o ofício do diretor apresentaram-se a ele, de maneira significativa, na seguinte experiência:

Quando fui para a Europa pela primeira vez, em 1966, enquanto o Oficina fazia Os Inimigos, de Górki, estava decidido a parar com o teatro. Lá veio a descoberta definitiva, na plateia do Berliner Ensemble. E depois em Varsóvia, em Praga, nos espetáculos de Planchon, na última direção de Piscator (que faleceu quando eu estava em Berlim). O teatro poderia ser 'como o cinema'! Ou seja, poderia ter um significado visual, uma gramática gestual precisa e inesgotável. Foi um encontro decisivo. Descobri a 'escrita cênica', como diz Planchon. Assisti a muitos espetáculos sem compreender a língua que os atores falavam, mas compreendia exatamente o sentido do texto e o significado da encenação. Acho que o diretor, em mim, nasceu aí. (PEIXOTO, 1989a, p. 113-114)

O seu horizonte artístico estava definido. O teatro não deveria, de forma alguma, tornar-se mero entretenimento e sim ser capaz de articular formação cultural ao exercício da crítica, com vistas a construir uma identidade social e política para o país. Contudo - diferentemente dos integrantes do Teatro de Arena, que tinham no texto teatral o eixo de suas investigações -, Peixoto empreendeu suas reflexões em torno da cena, isto é, como traduzir cenicamente as premissas contidas nas peças selecionadas. Qual linguagem artística deveria ser utilizada? Como novos recursos poderiam ser incorporados sem, com isso, perder a dimensão crítica e realista da cena teatral?

\section{De O rei da vela a Don Juan: no teatro como ator e diretor}

Com esses questionamentos na bagagem, Fernando retornou ao Brasil no período em que o prédio do Teatro Oficina fora consumido por um incêndio, em 1966. Diante de tal infortúnio, o grupo iniciou uma retrospectiva de seus trabalhos mais significativos. A temporada paulistana ocorreu no Teatro Cacilda Becker e a carioca no Teatro Maison de France.

No Rio de Janeiro, o elenco fez vários cursos de atualização. Dentre os que merecem destaque estavam o Laboratório de Interpretação Social, ministrado por Luís Carlos Maciel, e o de Filosofia e Pensamento Cultural, sob a responsabilidade de Leandro Konder. Nesse processo de caráter formativo, os jovens artistas entraram em contato com os estudos de Antonin Artaud, 
Bertolt Brecht e foram apresentados à peça $O$ Rei da Vela (Oswald de Andrade), escrita em 1933, cuja encenação acabou se tornando o grande marco da trajetória do Oficina e, também, do teatro brasileiro.

Naquele momento, Fernando Peixoto era dos integrantes do Oficina mais bem preparados no nível intelectual e profissional, pois, além de haver feito o curso de teatro, o contato com Ruggero Jacobbi dera-lhe a chave para sua vivência artística, a saber: não desenvolver sectarismos por antecipação, estar aberto a novas investigações e, principalmente, conhecer. Mesmo tendo sido, desde muito jovem, militante do Partido Comunista Brasileiro (PCB), ele não se fechou a possibilidades interpretativas, distintas das orientações do Partido, haja vista que participou ativamente das discussões e do processo de trabalho que trouxeram, pela primeira vez, para o palco o texto de Oswald de Andrade e, a ele coube a interpretação da personagem Abelardo II.

Nesse período, revelou também aguçado interesse por iniciativas estéticas e políticas realizadas nos Estados Unidos, como ilustra um artigo seu, a respeito do grupo teatral Bread and Puppet, publicado no Correio da Manhã (Rio de Janeiro), em um suplemento especial:

A companhia que nos últimos anos tem mais chamado a atenção dos que se preocupam com o movimento teatral não-conformista norte-americano é a Bread and Puppet, funcionando em Nova York há sete anos. [...] O que mais impressiona nos trabalhos do Bread and Puppet é a pesquisa permanente, uma elaboração formal, cuidada e trabalhada em minúcias, uma intensa revalorização do teatro como ritual, forma de captar uma realidade no que ela possa ter de mais profundo, tudo através de um trabalho de redescoberta da força expressiva e simbólica do gesto, do movimento econômico mais exato e da utilização do som como linguagem do espetáculo. No Bread and Puppet os 'atores' não aparecem sem máscaras: estão sempre envoltos em roupas que escondem seus corpos inteiros; os rostos são igualmente escondidos por máscaras. E representam ao lado de fantoches e marionetes.

[...] Quando assisti Fire, em Paris, o espetáculo terminou num silêncio mortal, os espectadores se retiraram em silêncio, falando baixo. Um dos integrantes do grupo me disse logo depois: 'Hoje funcionou bem. A gente sempre tem a prova no fim: quando eles aplaudem é porque saiu ruim: [...] Todo um ritual. Schumann afirma: 'O teatro precisa ser um alimento tão essencial como o pão'. (PEIXOTO, 1989a, p. 85-86, 90) 
Essa percepção é um dos exemplos que denotam a singularidade intelectual de Fernando Peixoto. Mesmo estando próximo de uma interpretação política que advogava a pertinência da frente de resistência à ditadura militar, ele refletiu sobre possibilidades que iam além da proposta realista. Foi nesse período que Peixoto passou a se interessar mais sistematicamente pelo dramaturgo e teórico alemão Bertolt Brecht ${ }^{4}$. Além disso, a cultura norte-americana, contestatória ao status quo, foi muito instigante para a constituição de sua reflexão crítica, como atesta, em 1968, a direção do espetáculo Poder Negro (LeRoy Jones).

Como Franz Fanon, o escritor negro que melhor analisou a situação trágica dos povos do terceiro mundo, Jones é um poeta da violência. Sua aspiração, seu projeto mais íntimo, talvez seja o de seu grande personagem: eu talvez venha a ser o grande poeta do futuro! Tudo que é preciso é dar um golpe de faca! E mais adiante: Matar!...Isso deixaria todos nós curados! A doença de Jones é a dos negros norte-americanos. [...] Todo o teatro de LeRoy Jones é um teatro de vítimas. Que se dirige a um público formado também por vítimas. Estabelece aí sua comunicação em The Dutchman (título intraduzível - literalmente significa o holandês, mas é usado para designar o não-integrado), o espectador é colocado diante de duas sociedades em luta agressiva: a que provoca, a que é provocada e que, reduzida a objeto, a animal, se revolta. Seu herói é evidentemente negro, mas ele mesmo tem suas contradições, prefere ficar protegido e escondido em suas palavras, sua obra literária. Importa o julgamento de seu comportamento na guerra fria ou quente em que está envolvido.

No final, Jones mostra o comportamento dos restantes personagens que passam da indiferença criminosa à adesão ao assassinato camuflado em legítima defesa. $O$ texto é violento, agressivo, poético. Seu personagem é um desesperado. E Walter Benjamin afirma que é nos desesperados que reside a esperança. (PEIXOTO, 1989a, p. 117)

Esse texto, originalmente publicado no programa do espetáculo, revela sua compreensão do processo vivenciado. A luta contemporânea não pode ser resumida somente à existência de classes sociais. Ela tem de ser capaz de abarcar diferentes perspectivas e permitir ao artista observar as especificidades de cada momento histórico para assumir a atitude mais adequada a seu próprio tempo. Nas abordagens de Peixoto, o campo da resistência

4 Na década de 1960, Fernando Peixoto recebeu o convite de Leandro Konder para escrever o livro Brecht, vida e obra, cuja primeira edição foi de 1968. 
democrática não possuía uma única orientação e seus trabalhos não se restringiram a temáticas exclusivas.

Sob esse prisma, qual perspectiva norteou a atuação de Fernando Peixoto, na década de 1960? Como compreender esse artista, que guardava proximidade teórica e artística com profissionais como Gianfrancesco Guarnieri e Augusto Boal, ao lado de grande interlocução com Zé Celso Martinez Corrêa?

As suas iniciativas não podem ser compartimentalizadas em um único nível de expectativas. Se a bandeira da resistência democrática estava em seu horizonte político, essa, por sua vez, não poderia estar localizada somente no retorno ao Estado de Direito, mas também no questionamento de relações excludentes e autoritárias forjadas no cotidiano das pessoas e das cidades. Nesse sentido, somente as denúncias não eram suficientes. Pelo contrário, as alternativas deveriam ser apontadas e uma delas implicava construir uma relação de cumplicidade e de envolvimento com a população. Nesse sentido, as experiências do Bread and Puppet, além de serem instigantes como proposta cênica, eram altamente motivadoras, porque eram contrárias ao teatro como provocação, ou como afirmou Schumann "não adianta chocar o espectador. Isso irrita. Ele fica contra. Não adianta insultar. É preciso conquistá-lo, atraí-Io" (PEIXOTO, 1989a, p. 88).

Essa ideia veio ao encontro das proposições de Peixoto de dar à cena dimensões sociais e políticas. Com esse propósito, participou como assistente de direção e ator da montagem de Galileu Galilei, em 1968, e, em 1969, da encenação de $\mathrm{Na}$ selva das cidades, ambas de autoria de Bertolt Brecht e direção de José Celso Martinez Corrêa.

Esses trabalhos foram extremamente vigorosos no diálogo com a conjuntura brasileira do período. O primeiro estreou no dia 13 de dezembro de 1968, data da promulgação do Al-5, e trazia como temática a questão da intolerância e da apropriação pública do conhecimento, isto é, a quem ele serve? Quais os desdobramentos do poder sobre a ciência? O segundo, por sua vez, tornou o próprio palco uma metáfora, ambientou os conflitos sociais em um ringue de boxe.

À luz desse repertório dramatúrgico, vislumbram-se os interesses de Peixoto. No entanto, o processo de trabalho e as disputas de bastidores acirraram os conflitos que já estavam latentes. A luta entre os representativos $e$ o coro tinha o objetivo de fazer com que uma proposta de encenação coletiva 
dominasse a cena. Entretanto, essas disputas não ficaram reduzidas ao nível do palco. As divergências levaram em conta, inclusive, aspectos das vidas particulares dos integrantes do Oficina, permitindo situações de agressão entre diversos profissionais.

Apesar da contínua radicalização, o trabalho teve continuidade. Todavia, as relações estavam cindidas e, durante as férias, Peixoto fez uma excursão internacional com o Arena, participando dos espetáculos Arena conta Zumbi e Arena conta Bolívar, enquanto os demais envolveram-se com a realização do filme Prata Palomares.

No retorno às atividades, Fernando Peixoto propôs-se a encenar Don Juan (Molière). Sem apoio do grupo, contou com a participação de Gianfrancesco Guarnieri e Flávio Império, ambos recém-saídos do Teatro de Arena. E, mais uma vez, enfrentou o debate proposto pelo próprio Oficina: "racionalistas" x "irracionalistas."

Eu voltava das ruas de New York, do Village percorrido e vivido cada noite, voltava de espetáculos que mergulhavam na busca de uma linguagem teatral descompromissada com o confronto sócio-político, imersos na pesquisa do chamado 'teatro de envolvimento', e me deixava envolver por ela, onde o papel predominante era a chance de criação coletiva, concebida como instrumento para o improviso entre atores e público, unidos num mesmo ritual sem limites, no qual os mais jovens e ousados encenadores e orientadores dos grupos buscavam a realização de uma utópica redescoberta do teatro como ato físico, sensual, irracional. A transformação do texto de Molière num roteiro para uma 'ópera-rock' foi a consequência direta desta experiência vivida em meses de Berkeley a New York. (PEIXOTO, 1989a, p. 137)

Essa montagem contribuiu para o adensamento do perfil intelectual e político de Fernando Peixoto, um dos grandes entusiastas do texto e do espetáculo $O$ Rei da Vela e do filme Terra em transe, pois neles enxergou possibilidades críticas até então não vislumbradas em outras manifestações. Ao mesmo tempo, participou de trabalhos concebidos em afinidade com o realismo crítico e com mensagens políticas expostas de forma mais direta, como Arena conta Zumbi e Arena conta Tiradentes, postura que o aproximava de artistas como Augusto Boal. Esse trânsito permitiu-lhe mergulhar em referências que não compunham o repertório e as discussões daqueles que estavam mais próximos ao PCB. 
Tal debate revela que escolhas e posicionamentos de determinados artistas e/ou segmentos não podem ser generalizados como norma de conduta. A disponibilidade de Peixoto para o diálogo demonstrou o nível de politização e de debate inerentes ao tema da contracultura e seu potencial de radicalismo e transformação ${ }^{5}$. Contudo, mesmo estando disponível para esse diálogo, as divergências acentuaram-se e, após Don Juan, Fernando deixou o Teatro Oficina. Encerrou-se, assim, uma parceria de quase dez anos, com a seguinte avaliação:

Quando encenei Dom Juan de Molière resolvi, num ímpeto, romper com tudo: retirar, inclusive, as poltronas do teatro, abolir a separação entre plateia e espetáculo, em termos de espaço pré-determinado. As cenas assim representadas onde houvesse espaço. O público se afastaria, e isto aconteceu, para permitir este espaço, se fosse necessário. Depois redescobri o potencial criativo do palco italiano. Na verdade, cada espetáculo deveria ter um espaço específico para si mesmo, que atenda às suas necessidades intrínsecas, sem qualquer tipo de imposição. $O$ espaço teatral ideal, hoje, é o espaço vazio, com condições técnicas para se transformar, em pouco tempo, e com poucos recursos, em qualquer tipo de dispositivo cênico proposto pela livre concepção do espetáculo. O encenador, que hoje, censurado, trabalha inseguro e humilhado, em certo sentido, já começa condicionado pelos limites do espaço que dispõe ao ser alugada uma determinada sala. Mas esta liberdade não poderá ser confundida com a ideia de buscar uma linguagem isenta da contribuição do passado. A vanguarda pela vanguarda nada significa. Os saltos qualitativos surgem dos quantitativos. Um extraordinário pensador deste século já declarou: é preciso construir com os tijolos que existem, com os que nos deixaram. E Lênin se referia a construir uma sociedade nova! (PEIXOTO, 1989a, p. 231)

\section{A presença do diretor na construção da resistência democráti- ca na década de 1970}

O processo pelo qual passou Fernando Peixoto é extremamente singular, pois, para ele, o debate político e estético não era meramente dicotômico. Esteve aberto a outras possibilidades e experiências, mas não compactou nem com o caminho sem volta, pelo menos, naquele momento, de Zé Celso M.

5 É importante destacar que as questões que nortearam o movimento hippie e a própria contracultura foram objetos de reflexão de Oduvaldo Vianna Filho em sua peça Rasga Coração (1974). Esta discussão foi por mim desenvolvida no Capítulo 4 do livro Vianinha: um dramaturgo no coração de seu tempo. 
Corrêa, nem com a luta armada. Optou por continuar atuante nos limites de sua coerência. Assim sendo, como se situar, na cena teatral, na década de 1970?

A luta pelo retorno do Estado de Direito era imprescindível e, diante dela, Fernando Peixoto não se omitiu. Apesar de nunca ter sido produtor teatral, ele, como ator e diretor, na maioria das vezes, compatibilizou suas posturas políticas e profissionais, especialmente, em virtude do círculo de sociabilidade ao qual sempre pertenceu. Todavia, isso não significou omissão perante as contradições entre capital e trabalho existentes no âmbito da cena teatral.

Os chamados 'artistas' vivem um conflito básico, que vivenciam muitas vezes até mesmo de forma consciente ou inconscientemente masoquista: são empregados assalariados, mas se recusam a se considerarem como tais. E estão presos a uma série de outros objetivos que em suas vidas é fundamental - em alguns a realização de algum projeto cultural ou social em termos de cultura, em outros a realização narcisista ou a desmedida busca da fama e do reconhecimento público. Para atingirem estes dois últimos projetos, aceitam tudo. Ou quase tudo. [...] Num texto sobre o significado da profissão ator, Bertolt Brecht dispensou, com inteligência, a distinção entre as diferentes motivações que podem justificar o exercício da atividade por um ator ou atriz, para colocar o problema em seu aspecto essencial: 'Em primeiro lugar vou falar da tua profissão, da indústria do espetáculo, da atividade que você escolheu exercer, não importa porque razões, esperamos que elas sejam as melhores. Na verdade, é indiferente o que você pretende fazer nesta profissão. O que você deve saber é o que farão de você. Os teatros de estado subvencionam os serviços que favorecem as ideias dominantes. Ou seja, as ideias daqueles que dominam, como daqueles que são dominados. É bom que você saiba que você é um empregado como qualquer outro empregado. (PEIXOTO, 1989b, p. 197-198)

Fernando Peixoto possuía clareza do seu lugar no mercado de trabalho e sabia que, como profissional, estava sujeito às oportunidades que surgissem. Apesar de não constituir caráter formal, nos anos 1970, ele desenvolveu suas atividades com grupos com os quais compartilhava a necessidade de fazer oposição à ditadura militar. Em verdade, os seus produtores eram, em sua maioria, artistas e antigos companheiros do Arena e do Oficina, que almejavam construir uma cena teatral que pudesse, ao mesmo tempo, denunciar o arbítrio e conclamar o retorno às liberdades democráticas.

Para que o intento fosse alcançado, o processo criativo não poderia ser desenvolvido por meio de uma linguagem direta. Ao contrário, essa alternativa de 
luta materializou-se em uma estratégia conhecida como linguagem da fresta, que se notabilizou pelo uso da metáfora e de temas históricos, com vistas a tornar o passado um escudo, a partir do qual se poderia refletir sobre o presente.

O primeiro convite para direção ocorreu em 1972, quando jovens atores, integrantes do Núcleo 2 do Teatro de Arena, optaram por continuar a participar da cena teatral paulistana e fundaram o Núcleo. Mas, como e onde se apresentarem? Novamente, a rede de solidariedade atuou em favor de uma causa maior e Maurício Segall, que estava à frente do Theatro São Pedro, cedeu-Ihes uma sala no piso superior do teatro, o Studio São Pedro.

\begin{abstract}
Na verdade, era o Celso Frateschi, Denise Del Vecchio, Dulce Muniz, Hélio Muniz, marido da... e não é bem que eu cedi o Teatro São Pedro, não. Nós tivemos uma conversa e fomos fazer um trabalho conjunto. $E$, de fato, havia uma dicotomia no Teatro, havia o Teatro grande embaixo, setecentos lugares, que se prestava a grandes espetáculos, ballet, orquestra e tudo mais: o Estúdio para espetáculos menores, e que tinha uma vocação de você fazer um teatro que não fosse um teatro...popular não é o termo, realmente, mas um teatro mais coletivo, vamos dizer assim, de criação coletiva. E o Estúdio era. E a idéia era que esse Núcleo, que tinha um trabalho já feito no Arena, muito rico, se incorporasse a esse conjunto que era o Edifício São Pedro e começasse a participar dessa vida que era muito democrático lá. (SEGALL, 1996, p. 6)
\end{abstract}

O lugar fora definido, o texto selecionado e os atores escalados. Faltava escolher o diretor do espetáculo, que fosse capaz de propiciar um instigante diálogo entre arte e sociedade. O nome escolhido foi o de Fernando Peixoto que, pela primeira vez, dirigiria um texto brechtiano.

Apesar de haver participado intensamente das montagens de Galileu Galilei e de Na selva das cidades, foi essa direção que ampliou o olhar brechtiano de Fernando Peixoto para a cena. Um trabalho que fosse capaz de, por um lado, envolver o espectador em suas proposições e, por outro, suscitar reflexões sobre o espetáculo e sobre a sociedade que o acolhe. Desse ponto de vista, o tema não poderia ser mais apropriado. Em primeiro lugar, a peça era uma reflexão sobre a derrota de um processo revolucionário. Em termos factuais, falava-se sobre a derrocada da Liga Espartaquista, em 1918, na Alemanha. Em termos metafóricos, era um exercício de compreensão das recentes derrotas da esquerda brasileira, que tivera parte significativa de seus quadros morta 
em combate e/ou nos porões da ditadura. Entre os que sobreviveram, muitos foram para o exílio. Todavia, os que aqui ficaram assumiram o compromisso de refletir sobre a derrota e criar condições de luta em outras bases.

Tambores na noite apontava um caminho e o interlocutor, nesse diálogo, não seria, como alguns tanto sonharam, os segmentos populares e sim os setores médios da população, aqueles que voltam para casa, como sintetizou Brecht. Enfim, como atuar nos limites da expectativa desse público potencial e não romper os compromissos assumidos na luta iniciada nos primórdios da década de 1960? Nesse ambiente, recuperar o estado de normalidade democrática passou a ser uma conquista histórica a ser obtida e Tambores apontava o caminho.

Ao Theatro São Pedro, agregaram-se profissionais, como o dramaturgo Carlos Queiroz Telles, os cenógrafos Helio Eichbauer e Gianni Ratto (este último também diretor teatral), o assistente de direção Mário Masetti, entre outros. Essa equipe, ainda em 1972, foi responsável por mais dois trabalhos: A semana e Frei Caneca, ambos de autoria de Carlos Queiroz Telles, com direção de Fernando Peixoto e cenários de Helio Eichbauer. No elenco, além de integrantes do Núcleo, para o espetáculo Frei Caneca foi convidado, a viver o papel-título, o ator Othon Bastos.

O projeto sobre os modernistas nasceu por iniciativa do próprio São Pedro, não com a perspectiva de investigar acontecimentos consagrados como a Semana de Arte Moderna, mas de refletir sobre o seu impacto no debate da década de 1970.

O texto de autoria de Carlos Queiroz Telles foi escrito em sintonia com as proposições cênicas de Peixoto e Eichbauer que, nesse momento, retomaram um diálogo iniciado em 1967, quando o primeiro interpretou Abelardo II e o segundo assinou os figurinos e os cenários de $O$ Rei da Vela. Sob esse aspecto, os dois artistas foram fundamentais para a construção de um olhar cômico, pois, juntamente com os demais integrantes do Oficina, foram artífices de uma releitura pública do Modernismo à luz do olhar antropofágico de Oswald de Andrade.

As personagens, em cena, passaram a refletir sobre impacto dos acontecimentos de 1922. Com a utilização de vários recursos cênicos (slides, projeção cinematográfica, cartazes, implosão do espaço cênico), o diálogo entre passado e presente ocorreu a partir de muitas perguntas. 1922 indaga em 1972: Valeu à pena? O país mudou? 
O texto de Queiroz Telles foi concebido tal qual um roteiro, em uma perspectiva coletiva. As rubricas descreveram a movimentação das personagens, no espaço do próprio Theatro São Pedro, com vistas a materializar uma ideia de não celebração nem da data, nem de um grupo. O objetivo era o de fornecer, ao espectador, o maior número de informações sobre o processo histórico, com ênfase nos impasses e nos conflitos inerentes a ele.

Já a peça Frei Caneca, que teve o texto dividido em dois atos, compostos por cinco cenas (três no primeiro e dois no segundo), trouxe momentos da vida de Frei Caneca quando menino e, posteriormente, como revolucionário em 1817 e 1824. Embora no palco fossem rememorados diferentes momentos históricos $(1799,1817,1824)$, nos quais o rompimento dos laços coloniais e o estabelecimento da república fundamentavam o debate, a amplitude e a abrangência das discussões permitiram que o tema fosse atualizado, isto é, a liberdade poderia ser estendida a outras situações: como celebrar uma luta que no passado fora justa e, na década de 1970, era interpretada como subversiva?

Em verdade, o conteúdo temático ganhou contornos e significados contemporâneos a partir do momento em que os diálogos foram construídos e/ou ditos com intenções dúbias. Um exemplo desse procedimento ocorre quando o Cego diz ao Menino das Canecas "em tempo de tanta intriga, é melhor a gente não ter nome certo não".

Essa advertência dita em palcos brasileiros, em meados de 1972, permitiu uma cumplicidade entre palco e plateia, isto é, por meio de um saber histórico comum, falava-se de algo que não poderia ser explicitado: a ditadura militar e os instrumentos com os quais ela governava a sociedade, fundados na repressão política e cultural.

Com efeito, percebe-se que o conteúdo histórico e as interpretações elaboradas estiveram a serviço da principal bandeira da resistência democrática: o Estado de Direito. Embora existissem temas importantes que também foram abordados, tais como: injustiça social, exploração do trabalho, entre outros, no campo da luta pela redemocratização eles tornaram-se auxiliares de uma luta maior.

Dessa feita, as datas, vistas como efemérides pelos órgãos governamentais, instantes de celebração e de afirmação da identidade nacional, para os artistas do Theatro São Pedro, tornaram-se oportunidades para questionar interpretações vistas como homogêneas em relação a esses símbolos. 
Ainda no São Pedro, em 1973, Fernando Peixoto encenou um de seus trabalhos mais festejados: Frank $V$, de Friedrich Dürrenmatt, dramaturgo suíço que, embora não fosse um árduo defensor do socialismo, era um feroz crítico do sistema capitalista. Sobre ele, Peixoto fez a seguinte avaliação:

Há diferenças radicais entre a sua obra e a de Bertolt Brecht. Dürrenmatt não aceita a vinculação de Brecht ao movimento comunista, mas reconhece que a obra do poeta e dramaturgo alemão é uma sincera resposta ao nosso mundo, à nossa culpabilidade. Entretanto, se a perspectiva de Dürrenmatt não é diretamente política, é possível encontrar analogias entre a sua dramaturgia e a de Brecht.

O crítico Bernard Dort, referindo-se a Frank V, acentua que a perspectiva de Dürrenmatt é religiosa. É um religioso em quem a formação protestante oferece o instrumental para a revolta: o resultado é uma indignação profunda, implacável. Sob muitos ângulos Frank $V$ é uma resposta à Ópera de três vinténs, de Brecht. Dürrenmatt acentua outros valores, mas conserva inúmeras colocações.

Mas não é, como A Ópera, um texto dialético. Antes, um paralelepípedo, arrancado das ruas do mundo em que vivemos. E lançado com fúria, cinismo e violência sobre as instituições e valores que garantem a sobrevivência de uma ordem socioeconômica injusta. Uma ópera não de mendigos, mas de milionários. Dirigida a um público que paga caro para ver teatro.

[...] A peça não é apenas a história de um banco: é a parábola do nosso mundo, da nossa sociedade, da nossa realidade.

Frank $\mathrm{V}$ é um paralelepípedo lançado contra determinados valores socioeconômicos e políticos. É um texto divertido ao extremo, mas também agressivo. Também queremos lançar este paralelepípedo contra o público. Mas não para feri-lo fisicamente. Este paralelepípedo deverá ficar parado, imenso, ameaçador. A um centímetro da cabeça do público. É preciso que o espectador encare de frente esta realidade que the é mostrada deformada, teatralizada. Sinta seu peso, seu significado: pense. Hoje, mais do que nunca, o teatro brasileiro está se encaminhando para desempenhar uma tarefa imbecil: anestesiar o espectador, mistificá-lo, envolvê-lo num mundo mágico e falso da fuga e fantasia, reduzi-lo a objeto a ser hipnotizado. A diversão está, assim, a serviço do aniquilamento de cada um enquanto ser humano responsável e inteligente. A nós, ao contrário, interessa despertar o sentido crítico do espectador: mantê-lo vivo, atuante, consciente, respeitá-lo como ser humano livre, capaz de aprender e ensinar, capaz de discutir, refletir, modificar. (PEIXOTO, 1989a, p. 144-146)

Essa análise publicada originalmente no programa do espetáculo, além de propor uma interpretação sobre a montagem e o texto, apresentou-se como 
um convite à reflexão e à necessidade do estabelecimento de uma consciência social. Para tanto, a proposta reflexiva estabeleceu uma relação de estranhamento com o próprio espetáculo, por meio da concepção brechtiana de Fernando Peixoto de compreender e fazer teatro, que assumiu, talvez, nessa encenação uma de suas formas mais acabadas. Frank $V$ foi o último trabalho de Fernando Peixoto no Theatro São Pedro.

Ainda em 1973, Peixoto recebeu de Chico Buarque e Ruy Guerra um convite irrecusável: dirigir Calabar, o elogio à traição, espetáculo que seria produzido por Fernanda Montenegro e Fernando Torres. Com essa proposta, mais uma vez, ele se via em uma situação na qual teria oportunidade de colocar no palco um espetáculo que vinha ao encontro de suas expectativas como artista, cidadão e militante.

O tema da traição, nada mais adequado para um país que adotava como propaganda oficial Brasil, ame-o ou deixe-o. E, desse ponto de vista, estar contra o governo era estar na condição de traidor. Porém, escudados, mais uma vez, em acontecimentos históricos, os dramaturgos indagavam: o que é a traição? Em que condições, alguém pode ser taxado de traidor? Quem é que trai e quais as circunstâncias deste ato?

Compreender historicamente o mulato Calabar significava relativizar uma ideia que, sob a ótica dos militares, estava bem definida: traidor é quem se opõe ao regime militar. Mas, todos aqueles que se opuseram ao governo, estando mortos ou vivos, eram traidores do país?

Aquele espetáculo tinha como proposta estabelecer essa discussão em um musical, em que as músicas de autoria de Chico Buarque (algumas em parceria com Ruy Guerra) tornaram-se um capítulo à parte: Tatuagem; Cala Boca, Bárbara; Vence na vida quem diz sim; Fado Tropical; Boi voador; Não existe pecado ao sul do Equador; etc. Nesse aspecto, a peça era polissêmica, comportando distintas interpretações e apropriações diferenciadas.

Em uma produção que envolveu um elenco com mais de trinta atores, músicos, direção musical de Dori Caymmi, cenários e figurinos de Hélio Eichbauer, dentre os vários profissionais envolvidos, Calabar consumiu meses para seleção do elenco, de ensaios e concepção geral da montagem. $E$ todo esse trabalho resultou em vão porque na véspera da estreia, no dia do ensaio geral para a censura, a encenação foi censurada. $O$ que fazer? Fernando Peixoto registrou esses momentos da seguinte maneira: 
31.10.73 - Bandeiras, telões de boca, mais objetos e mais adereços! A estrutura visual do espetáculo vai ganhando coerência e adquirindo peso na narrativa. A cenografia de Hélio tem um vigor épico expressivo. Mudei o ritmo do ensaio: só correções, transições, correção de certos detalhes. Principalmente no primeiro ato. Mas consegui ir até o fim. Ter passado tudo teria sido inútil. Consigo mais coerência interna na articulação das últimas cenas. Mas Anna e Bárbara ainda me preocupam. Não achamos os objetos certos para a paramentação de Bárbara. Ou é o texto, ou o encaminhamento de interpretação, ou minha concepção (que, aliás, é vaga e montada em cima de certa resistência que tenho, desde o início com esta cena). O 'povo' tem que ocupar mais espaço e ocupar melhor o espaço, que é bem maior, exige uma disposição cênica mais dinâmica. De resto, como sempre, a tarde foi cheia de baldes de água fria. Chegou Fernando com a carta da Censura, sobre a tal de 'avocação' da peça pra instância superior. Com esta palavrinha superior, esconde mentiras. A carta praticamente proíbe o espetáculo. Caracteriza uma censura econômica. É datada de 30 de outubro. A censura política nem chega a ser exercida. A censura foi censurada, proibida de proibir. Os gastos estão feitos. Que vai acontecer de agora em diante, se a proibição for mantida, com os produtores e os próximos espetáculos? Texto liberado não é mais garantia mínima.

07.11.73 - Continuam os ensaios. E as ameaças. Providências para filmar, como medida defensiva (guardar o que foi feito). Rose Lacreta assumirá a realização do filme/documento. A solidariedade é de todos: já temos três câmeras, profissionais dispostos a trabalharem na marra na imagem e no som. Estes últimos dias foram irritantes: exigiam certo heroísmo. Em certos momentos, claro, a vontade é largar tudo. Mas é esta nossa modesta frente de resistência: continuar. Ontem, dia 6, o ensaio foi feito de portas abertas. Cerca de duzentas pessoas. Nada está maduro, mas aplaudiram em cena aberta algumas cenas. Talvez tenha sido o primeiro e último espetáculo. [...] A vontade é engravidar o espetáculo de uma força política mais nítida e mais explicitada. Descubro, revendo uma cena já feita, o nível de autocensura que está enraizado no inconsciente: encontrei uma solução cênica sem dúvida correta e justa, mas tímida, acovardada. Só agora percebo isso. Só agora que sei que o espetáculo será proibido, percebo que esta cena deveria ser mais forte e seu significado deveria ter sido assumido cenicamente de forma mais consequente. A presença da censura me fez descobrir isso. (PEIXOTO, 1989b, p. 191-192)

Esses fragmentos sobre o processo de ensaio e as tensões decorrentes da ameaça da censura permitem que sejam entrevistos elementos que, muitas vezes, compuseram os bastidores dos ensaios teatrais. Nessas circunstâncias, a violência manifestava-se de outras maneiras: cerceamento 
econômico, guerra psicológica, insegurança quanto à continuidade do trabalho, enfim, tolher o próprio espaço de atuação dos profissionais de teatro. Esse expediente tornou-se fórmula muito adequada para estrangular economicamente produtores, de porte médio, que investiam no teatro, não só com um negócio, mas como um projeto político e intelectual.

Após viver essa situação, Fernando Peixoto, ainda em 1973, irá dirigir, pela primeira vez, um espetáculo para a Othon Bastos Produções Artísticas: Um grito parado no ar, de Gianfrancesco Guarnieri, que estreou em abril de 1973, no Teatro Guaíra, em Curitiba, e viajou para a maioria dos estados brasileiros, com lotação esgotada em quase todos os lugares em que se apresentou.

Essa montagem talvez seja a que mais representou os embates daqueles que optaram pelo teatro de resistência, pois, antes de qualquer ponderação, esse texto teatral é um instigante questionamento sobre o que significa fazer teatro em um momento de tensão e insegurança política e social.

Um grito parado no ar é uma representação do trabalho artístico em circunstâncias de opressão, materializadas no espetáculo pelas dificuldades financeiras: não conseguir pagar as prestações dos produtos adquiridos, manter o aluguel do espaço, quitar as despesas com o consumo de energia elétrica, além de não possuir verba para divulgar a estreia do espetáculo. Por meio de construções metafóricas, o espetáculo expunha a ação intensificada dos órgãos de censura e o asfixiamento das condições de produção, o que inviabilizou o surgimento e a continuidade de muitos trabalhos, aliás, prática que se tornou recorrente em períodos posteriores.

Essas novas condições exigiram de artistas e intelectuais, em geral, estratégias para a confecção de uma nova linguagem. E, sob esse aspecto, Um grito parado no ar é altamente exemplar, na medida em que esteticamente constrói os indícios dessa nova realidade, a começar pela própria concepção cênica, um palco semivazio, com uma mesa, alguns bancos, revelando a ausência de recursos. Por outro lado, essa opção também evidencia o privilegiamento da palavra no teatro, em uma resposta às propostas que decretavam a morte do texto e afirmavam, preferencialmente, a eficácia da imagem. Nessa linha de raciocínio encontram-se também as observações de Fernando Peixoto, diretor do espetáculo, ao dizer: 
declaração de princípios, a utilização consciente da linguagem teatral para uma reflexão crítica e impiedosa sobre o próprio teatro. Num momento de mistificação, de fugas, de misticismo, Guarnieri, talvez o dramaturgo brasileiro que melhor sabe provocar o riso e o choro na plateia, criando personagens marcados por um calor humano reconhecível e comovente, um escritor que sabe intuitivamente como criar situações emocionais irresistíveis, defende a vigência de uma arte racional, concreta como a verdade, livre e voltada para o potencial transformador dos espectadores. Apresentando seu grito parado no ar ele afirma ainda: Sem dúvida a palavra não morreu e na medida em que é tolhida mais se demonstra viva. [...] Guarnieri deixa evidente que boa parcela da crise do teatro brasileiro, do desespero de muitos de seus artistas, nasce de uma insegurança de trabalho, de ausências de condições materiais e psicológicas para o exercício da profissão. As causas de tudo isso são, em última análise, o trabalho idealista realizado sob a ameaça constante da censura, sobretudo da censura econômica, que hoje limita, mais que tudo, o desenvolvimento de um teatro livre, crítico, transformador, verdadeiro. (PEIXOTO, 1989a, p. 162-163)

Essas considerações, articulando o diálogo arte e sociedade, são extremamente profícuas, pois contribuem para que se explicite, de forma instigante, a historicidade da escrita e da cena teatral, legitimando-as como documentos de pesquisa, frutos de uma determinada época, e inseridos em embates culturais e disputas políticas, isto é, o código estético não deve ser apreendido acima dos conflitos de seu tempo, porque eles traduzem, no nível simbólico, representações que reelaboram projetos, lutas e sonhos de homens e de lugares específicos.

Um grito parado no ar talvez seja a tradução poética daqueles anos de chumbo para aqueles que optaram pela resistência democrática, pela luta estabelecida no dia a dia e, no âmbito teatral, para os que continuaram a ver nessa atividade artística um espaço significativo para o exercício da crítica ao status quo. Aliás, essas mesmas premissas nortearam Fernando Peixoto quando dirigiu Caminho de volta (Consuelo de Castro), em 1974, e Ponto de partida (Gianfrancesco Guarnieri), em 1976. A primeira organizou seus conflitos em uma agência de publicidade, com a finalidade de discutir sobre $\mathrm{o}$ impacto dessa atividade no campo das relações sociais, econômicas e afetivas. Já Ponto de partida nasceu de uma indignação: a morte do jornalista Wladimir Herzog, nas dependências do II Exército em São Paulo. Ambientada em uma aldeia medieval do século XII, discorria sobre quem poderia ter assassinado o poeta Birdo, que amanheceu dependurado em uma árvore, 
recurso semelhante ao da peça Calabar. Em ambas, as personagens desencadeadoras dos conflitos estão ausentes da cena, mas são capazes de impulsionar a ação dramática através do elemento épico instituinte da narrativa.

Fernando Peixoto, em diversas oportunidades, afirmou que esse era um de seus trabalhos mais bem-acabados, que teve boa acolhida de público e crítica e ficou mais de um ano em cartaz. Posteriormente, vieram, em 1977, Mortos sem sepultura (Jean-Paul Sartre) e Coiteros (José Américo). Em 1980, retornou a esse espaço teatral para dirigir a segunda versão de Calabar, o elogio da traição, produzida pela Othon Bastos Produções Artísticas e Renato Borghi.

Em síntese, as encenações de Peixoto, no decorrer da década de 1970, revelam, antes de quaisquer considerações, a presença de um artista que criou perspectivas para o florescimento de uma cultura de oposição. No entanto, com as redefinições políticas e culturais de meados da década de 1980 em diante, determinados temas e interpretações passaram a ser vistos como superados historicamente. Dentre as experiências suplantadas pela contemporaneidade estão as reflexões e os trabalhos da resistência democrática. Com isso, perspectivas teleológicas foram refutadas e o presente passou a ser a única temporalidade digna de indagação, como atesta a fala de Maurício Segall sobre o Theatro São Pedro, em evento ocorrido no Itaú Cultural, em São Paulo:

Eu acho que o Teatro São Pedro foi uma experiência muito importante enquanto viveu. Acho que ele não deixou sementes, o que é triste. Por isso que eu não gosto de falar muito. Eu vim aqui só mesmo para esse testemunho, porque para mim não é prazeroso isso. Nós fizemos muita coisa, mas teve repercussão? Eu diria que não. Eu acho que muitos de vocês, talvez $80 \%$, antes de começar a ver o programa, 'Ah, vai falar o cara do São Pedro. $\mathrm{O}$ que é o São Pedro?', antes disso sabiam o era o Teatro São Pedro? Não sei. Acho que não. Acho que realmente não. Aí a responsabilidade, em boa parte, recai também sobre os críticos, sobre essa coisa toda, e também daquilo que diz a Mariângela aqui. Ela diz que isso talvez fosse inviável, era anacrônico, não tinha mais nada a ver, não era por aí, o que era bem possível: aliar um teatro meio comercial, meio não comercial, meio profissional, meio não profissional. A Companhia estava fazendo isso. Era talvez, como ela disse, anacrônico e deu no que deu. Deu em nada! Essa é a visão que eu tenho do São Pedro, infelizmente. Eu acho que se for para tirar algumas lições disso, agora que a gente reaviva um pouco, é rediscutir essa questão do teatro: 0 que é teatro popular, essas categorias de teatro? O que são esses públicos? A nossa postura de não levar teatro à periferia, mas ir à periferia para formar 
grupos e fomentar grupos, era uma postura nossa. Era uma postura político-ideológica. (SEGALL, 1996, p. 18)

As questões apresentadas por Segall demonstram a importância de se refletir sobre esse momento de grande significação para as artes cênicas contemporâneas. Por esse motivo, retomando a inquietação com a qual este artigo se iniciou, acredito que uma das tarefas dos pesquisadores que se voltam para as experiências teatrais no Brasil seja a de compreender os motivos que justificam o esquecimento político e cultural de parte dos processos criativos da década de 1970 e, sob esse prisma, as realizações de Fernando Peixoto são um convite para que possamos mergulhar nesse caleidoscópio de projetos e percepções do mundo e das artes cênicas.

\section{Referências bibliográficas}

BRANDALISE, I. Travessa do carmo. In: PEIXOTO, F. Um teatro fora do eixo: Porto Alegre: 11953-1963. 2. ed. São Paulo: Hucitec, 1997.

GARCIA, S. (org.). Odisseia do teatro brasileiro. São Paulo: Editora Senac, 2002. MIRANDA, C. Apresentação. In: PEIXOTO, F. Ciclo de palestras sobre o teatro brasileiro. Rio de Janeiro: Fundacen, 1988. v. 9.

PATRIOTA, R. Antonio Fagundes no palco da história: um ator. São Paulo:

Perspectiva, 2018

PEIXOTO, F. Um teatro fora do eixo: Porto Alegre: 1953-1963. 2. ed. São Paulo:

Hucitec, 1997.

PEIXOTO, F. Meus textos, meus livros e as teclas da velha máquina. In: PEIXOTO, F.

Teatro em aberto. São Paulo: Hucitec: Primeiro Ato, 2002.

PEIXOTO, F. No confessionário (De Porto Alegre, 1953, até São Paulo, 1963). In:

PEIXOTO, F. Um teatro fora do eixo. 2. ed. São Paulo: Hucitec, 1997.

PEIXOTO, F. Teatro em movimento. 3. ed. São Paulo: Hucitec, 1989b.

PEIXOTO, F. Teatro em pedaços. 2. ed. São Paulo: Hucitec, 1989a.

SEGALL, M. Theatro São Pedro. In: SEMINÁRIO PELA PRESERVAÇÃO DA

MEMÓRIA DO TEATRO BRASILEIRO NO SÉCULO XX, 1., 1996, São Paulo.

Anais [...]. São Paulo: Instituto Itaú Cultural, 1996. (cópia digitada).

Recebido em 16/4/2019 Aprovado em 12/06/2019

Publicado em 30/08/2019 